\title{
Corporate social responsibility: an issues paper
}

\author{
Working Paper No. 27
}

\section{Michael Hopkins}

Policy Integration Department

World Commission on the Social Dimension of Globalization

International Labour Office

Geneva

May 2004 


\section{Copyright (C) International Labour Organization 2004}

Publications of the International Labour Office enjoy copyright under Protocol 2 of the Universal Copyright Convention. Nevertheless, short excerpts from them may be reproduced without authorization, on condition that the source is indicated. For rights of reproduction or translation, application should be made to the Publications Bureau (Rights and Permissions), International Labour Office, CH-1211 Geneva 22, Switzerland. The International Labour Office welcomes such applications.

Libraries, institutions and other users registered in the United Kingdom with the Copyright Licensing Agency, 90 Tottenham Court Road, London W1T 4LP [Fax: (+44) (0)20 7631 5500; email: cla@cla.co.uk], in the United States with the Copyright Clearance Center, 222 Rosewood Drive, Danvers, MA 01923 [Fax: (+1) (978) 750 4470; email: info@copyright.com] or in other countries with associated Reproduction Rights Organizations, may make photocopies in accordance with the licences issued to them for this purpose.

ISBN 92-2-116138-2 (printed version)

ISBN 92-2-116139-0 (web version)

First published 2004

Cover:

The designations employed in ILO publications, which are in conformity with United Nations practice, and the presentation of material therein do not imply the expression of any opinion whatsoever on the part of the International Labour Office concerning the legal status of any country, area or territory or of its authorities, or concerning the delimitation of its frontiers.

The responsibility for opinions expressed in signed articles, studies and other contributions rests solely with their authors, and publication does not constitute an endorsement by the International Labour Office of the opinions expressed in them.

Reference to names of firms and commercial products and processes does not imply their endorsement by the International Labour Office, and any failure to mention a particular firm, commercial product or process is not a sign of disapproval.

ILO publications can be obtained through major booksellers or ILO local offices in many countries, or direct from ILO Publications, International Labour Office, CH-1211 Geneva 22, Switzerland. Catalogues or lists of new publications are available free of charge from the above address, or by email: pubvente@ilo.org

Visit our website: $\underline{\text { Www.ilo.org/publns }}$ 


\section{Corporate social responsibility: an issues paper}

\section{Contents}

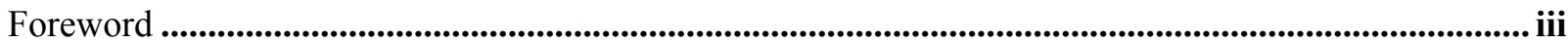

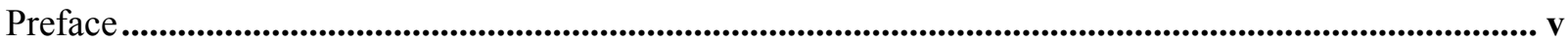

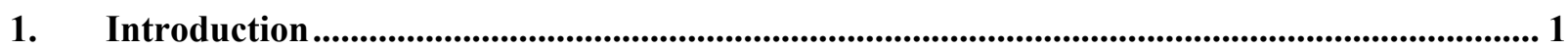

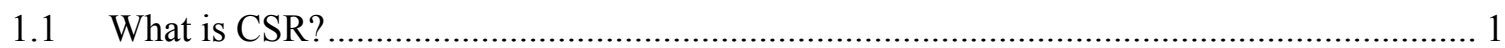

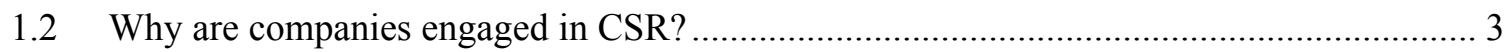

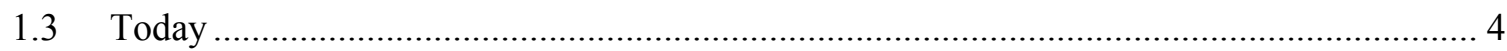

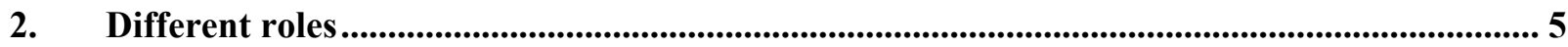

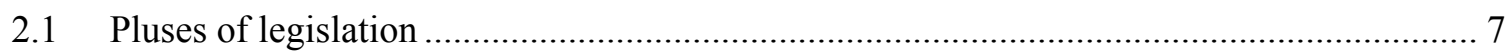

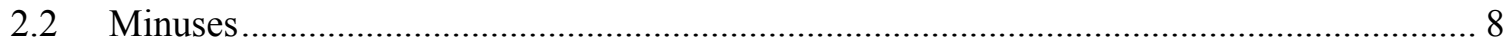

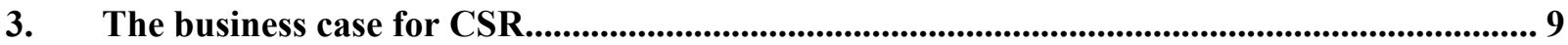

4. Benchmarks used by companies ................................................................................ 12

4.1 Overview of the content of codes .................................................................... 13

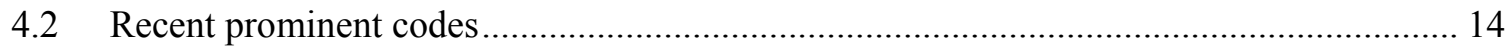

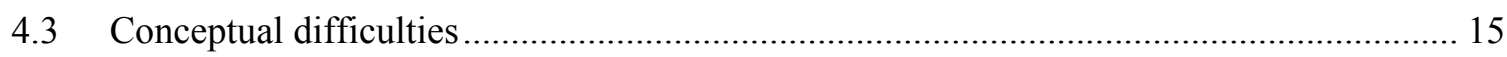

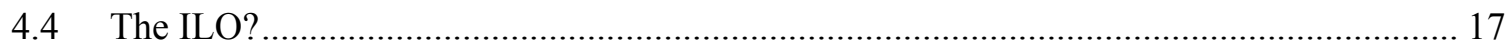

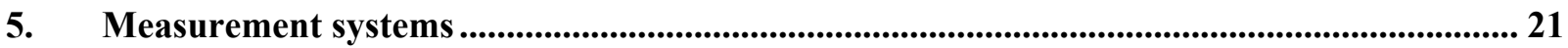

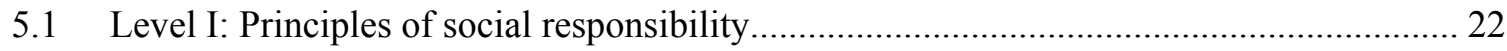

5.2 Level II: Processes of social responsibility ....................................................... 22

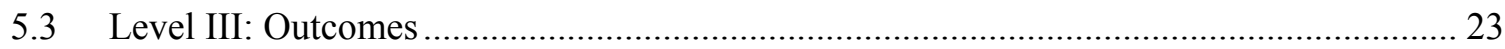

5.4 Applying the measurement CSR model: An example .............................................. 23

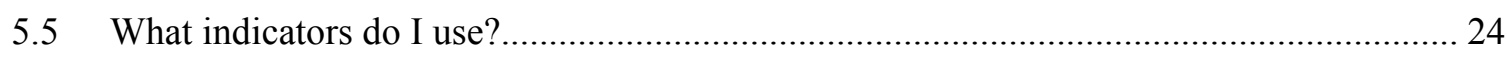

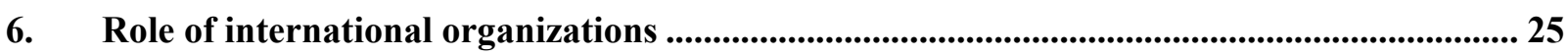

Annex I

Annex II............................................................................................................................................ 30

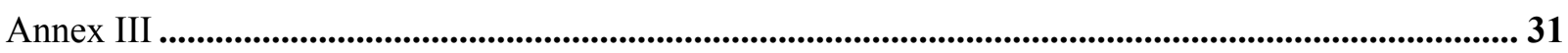





\title{
Foreword
}

In February 2002, the ILO established an independent World Commission on the Social Dimension of Globalization, co-chaired by President Tarja Halonen of Finland and President Benjamin Mkapa of Tanzania and comprising 26 eminent commissioners from a wide range of walks of life and different parts of the world, each serving in their individual capacity. Its broad goals were: to identify policies for globalization that reduce poverty, foster growth and development in open economies, and widen opportunities for decent work; to explore ways to make globalization inclusive, so that the process can be seen to be fair for all, both between and within countries; to promote a more focused international dialogue on the social dimension of globalization; to build consensus among key actors and stakeholders on appropriate policy responses; and to assist the international community forge greater policy coherence in order to advance both economic and social goals in the global economy.

The report of the World Commission, A fair globalization: Creating opportunities for all, was released on 24 February 2004. It is available on the Commission's website www.ilo.org/public/english/wcsdg/index.htm.

A secretariat was established by the ILO to support the Commission. Among other tasks, it compiled information and commissioned papers on different aspects of the social dimension of globalization. The aim was to provide the Commission with documentation and data on a wide range of options and opinions concerning subjects within its mandate, without committing the Commission or individual Commissioners to any particular position on the issues or policies concerned.

Material from this background work is being made available as working papers, as national and regional reports on meetings and dialogues, and in other forms. Responsibility for the content of these papers and publications rests fully with their authors and their publication does not constitute an endorsement by the World Commission or the ILO of the opinions expressed in them.

\author{
Gerry Rodgers \\ Director \\ Policy Integration Department
}





\title{
Preface
}

The Technical Secretariat to support the World Commission on the Social Dimension of Globalization first prepared a synthesis of ILO activities on the Social Dimension of Globalization (published as Working Paper No. 1 in this series). Documentation on the work and outcomes of other major commissions, an ideas bank, a database and knowledge networks of experts and social actors were subsequently developed. These networks have dealt with several topics, including: inclusion at the national level for the benefits of globalization to reach more people; local markets and policies; cross-border networks of production to promote decent work, growth and development; international migration as part of the Global Policy Agenda; international governance (including trade and finance); the relationship between culture and globalization; and values and goals in globalization. Gender and employment aspects were addressed throughout this work. The Reports on the Secretariat's Knowledge Network Meetings are available on the Commission's web site or in a special publication from the ILO (ISBN 92-2-115711-1).

During the course of these activities, a number of substantive background papers were prepared, which are now made available for wider circulation in the Policy Integration Department's Working Paper series (Nos. 16 to 38), as well as on the Commission's website.

Professor Hopkins, University of Middlesex; argues in this paper ( of which an earlier version was prepared for a knowledge network meeting on corporate social responsibility organised by José Guilherme Almeida dos Reis) that corporate social responsibility is not a new issue. Although, the social responsibility of business was not widely considered to be a significant problem from Adam Smith's time to the Great Depression, since the 1930s, and increasingly since the 1960 s, social responsibility has become an important issue .This concern for the social responsibility of business has even accelerated since the fall of the Berlin Wall and the onset of globalization. Global concerns have been given an additional edge by the awful events of 11 September. Also the recent collapse of some major companies in industrialised countries, has raised the level of scrutiny of large companies, as well as their auditors.

The author argues that, the need to address questions of low living standards, exploitation, poverty, unemployment and how to promote social development in general, has to date been almost entirely the preserve of governments. But, increasingly in the future, the promotion of social development issues must also be one of partnership between government and private and non-governmental actors and, in particular, the corporate sector. Until the 1970s, despite regulation and legislation, business continued largely along an autonomous path. But the decade of the 1960s was to be a period of enlightenment for many. Consumers had grown suspicious of adulterants in their food and dangerous defects in the products they bought. People were becoming aware of the fragile nature of the earth's ecology, while simultaneously becoming more cognizant of human rights. The author focuses in his discussions on corporate social responsibility on the largest companies, the transnational corporations (TNCs). Because of their often immense size, decisions about the location of investments, production and technology by TNCs not only influence the distribution of factor endowments, notably of capital, skilled labour and knowledge, between the countries in which they run their activities, but also assume crucial importance for their political and social consequences.

\author{
Rolph van der Hoeven \\ Manager, Technical Secretariat \\ World Commission on the Social Dimension of Globalization
}

May 2004 



\title{
Corporate social responsibility: an issues paper
}

1. Introduction

What is corporate social responsibility (CSR)? What are the key features of the various different private initiatives? Why are companies engaging in CSR initiatives and what are the internal and external driving forces behind them?

\subsection{What is CSR?}

There are a variety of definitions of CSR and no overall agreement. My own definition is: ${ }^{1}$

\begin{abstract}
CSR is concerned with treating the stakeholders of the firm ethically or in a responsible manner. 'Ethically or responsible' means treating stakeholders in a manner deemed acceptable in civilized societies. Social includes economic responsibility. Stakeholders exist both within a firm and outside. The natural environment is a stakeholder. The wider aim of social responsibility is to create higher and higher standards of living, while preserving the profitability of the corporation, for peoples both within and outside the corporation.
\end{abstract}

CSR therefore means the ethical behaviour of business towards its constituencies or stakeholders. Nevertheless, there are a wide variety of concepts and definitions associated with the term "corporate social responsibility", but no general agreement of terms. To provide some guidance to readers in this area I have included a glossary of terms ${ }^{2}$ in Annex I, which provides a number of definitions. Alert readers will notice, however, a fluidity of concepts that really requires more extensive research and consideration than has been undertaken so far. Without a common language, we do not really know whether our dialogue with companies is being heard and interpreted in a consistent way. To date I believe that such dialogue has been highly flawed, as some companies use the terms "corporate citizenship", some "the ethical corporation", while others use "good corporate governance" or "corporate responsibility". These flaws lead some companies to consider CSR as pure corporate philanthropy, others (such as Shell) as a new corporate strategic framework, while others dismiss the notion entirely.

In this context, a lively debate has led some authors, mainly academics based in the United States, to prefer to use the concept of "corporate social responsiveness", rather than "corporate social responsibility" per se. For example, they argue, Ackerman and Bauer ${ }^{3}$ among them, that the connotation of responsibility is that of the process of merely assuming an obligation. This places emphasis on motivation rather than performance but,

\footnotetext{
${ }^{1}$ The definition has been picked up elsewhere, for instance from the influential newswire service on CSR in the United States www.csrwire.com

2 These are drawn from the author's website www.mhcinternational.com, which is updated as definitions and concepts harden or improve. Readers are invited to place their own views on the site.

${ }^{3}$ Robert Ackerman and Raymond Bauer, Corporate social responsiveness: The modern dilemma, Reston, Virginia, Reston Publishing, 1976.
} 
they believe, such motivation is not enough, because responding to social demands is much more than deciding what to do; thus there remains the management task of doing what one has decided to do: this is social responsiveness. However, I believe that managers must accept the notion of social responsibility before they work out what to do. There is no argument about the fact that, once it has been accepted, the next step is the response, or in other words that acceptance of the motivation to be socially responsible immediately leads the manager into what should be done next, that is into social responsiveness. Acceptance does not, of course, come easily and much work is going on around the world to show that corporate social responsibility makes sound economic, as well as social, ethical, political and philosophical sense.

I include economic aspects in my definition of CSR simply because the study of economics is a "social" science which also encompasses financial aspects. Triple bottom line (TBL) is also implicit, since the third part of the triple is the environment, and I have always considered the environment to be one of the stakeholders of a company. Nevertheless, many prefer the term "corporate responsibility". In correspondence with the magazine Ethical Corporation, I took issue with their wish to drop the word "social". Their argument was that: ${ }^{4}$

CSR is confusing, not only to those that do not yet know what these three letters stand for, but also to those who do and yet see it used in contexts in which corporate environmental or financial performance is the issue (...) we prefer the simple 'corporate responsibility' because it's not at all confusing, does not exclude environmental and financial aspects of corporate performance and does not represent too great a departure from the current, unsatisfactory 'CSR'.

My own view, kindly reproduced in Ethical Corporation, ${ }^{5}$ is that using the term "corporate responsibility" (CR) instead of "corporate social responsibility" changes the nature of what the concept is all about. The term "social" is included by many practitioners to encourage corporations to look at their social responsibilities as well as their usual "responsibilities". To date, the main responsibility of a corporation has been to make profits for its shareholders. "Corporate responsibility" describes this very well. However, including "social" emphasizes the inclusion of other aspects, such as the wider economy, stakeholders other than shareholders and the environment. For instance, the International Business Leaders Forum fell into the CR trap when it announced in one of its press releases that, "President Bush addresses corporate responsibility" and then went on to say, "President George W. Bush has outlined a ten-point plan to "improve corporate responsibility and protect America's shareholders." The proposals are guided by the following core principles: providing better information to investors; making corporate officers more accountable; and developing a stronger, more independent audit system. Critics slam President Bush's ten pointer for lacking specifics, penalties, budget support and consideration of corporate social responsibility. But a closer look at the ten points reveals that the nearest President Bush got to corporate responsibility was when he announced:

\footnotetext{
${ }^{4}$ Toby Webb, “Editor's Notes”, Ethical Corporation Magazine, March-April 2002, p. 3.

${ }^{5}$ Michael Hopkins, “Letters”, Ethical Corporation Magazine, May 2002, p. 15.
} 
Proposal No. 8: An independent regulatory board should ensure that the accounting profession is held to the highest ethical standards. Under this proposal, an independent regulatory board would be established (...) to develop standards of professional conduct and competence. This board would have the ability to monitor, investigate, and where needed, enforce its ethics principles by punishing individual offenders.

Hardly what Ethical Corporation Magazine meant by its definition of corporate responsibility! It is just that much harder to avoid giving short shrift to the social part of corporate responsibility when you include the word "social".

\subsection{Why are companies engaged in CSR?}

Companies that are socially responsible in making profits also contribute to some, although obviously not all, aspects of social development. Every company should not be expected to be involved in every aspect of social development. That would be ludicrous and unnecessarily restrictive. But for a firm to be involved in some aspects, both within the firm and on the outside, will make its products and services (for example financial services) more attractive to consumers as a whole, therefore making the company more profitable. There will be increased costs to implement CSR, but the benefits are likely to far outweigh the costs.

Corporate social responsibility is not a new issue. The social responsibility of business was not widely considered to be a significant problem from Adam Smith's time to the Great Depression. But since the 1930s, and increasingly since the 1960s, social responsibility has become an important issue not only for business but in the theory and practice of law, politics and economics. In the early 1930s, Merrick Dodd of Harvard Law School and Adolf Berle of Columbia Law School debated the question "For whom are corporate managers trustees?" Dodd argued that corporations served a social service, as well as a profit-making function, a view repudiated by Berle. This debate simmered for the next 50 years, according to Gary von Stange, before it once again sprang into prominence in the 1980 s in the wake of the "feeding frenzy atmosphere of numerous hostile takeovers". This concern for the social responsibility of business has even accelerated since the fall of the Berlin Wall, which symbolized the collapse of communism and (more importantly) the onset of turbo-charged globalization

Further acceleration has occurred in the past few years. Global concerns have been given an additional edge by the awful events of 11 September. The collapse of Enron and WorldCom, and their auditor Arthur Andersen, due to dubious accounting practices, has raised the level of scrutiny of large companies, as well as their auditors. And this, at the time of writing, is in spite of the most company-friendly President of the United States known in modern times. Even the President has broached, albeit tamely, the notion of the responsibility of corporations. Moreover, previously quiet CEOs have begun to note the pressure. In a rare public appearance in June 2002, the Chairman and Chief Executive of Goldman Sachs, Henry M. Paulson Jr. noted, after the collapse of the Enron Corporation in late 2001, that "I cannot think of a time when business over all has been held in less repute."

\footnotetext{
${ }^{6}$ www.nytimes.com 5 June 2002.
} 
The need to address questions of low living standards, exploitation, poverty, unemployment and how to promote social development in general, has to date been almost entirely the preserve of governments. Clearly, they will continue to have $a$, if not the, major role to play in this area. But, increasingly in the future, the promotion of social development issues must also be one of partnership between government and private and non-governmental actors and, in particular, the corporate sector.

Until the 1970s, despite regulation and legislation, business continued largely along an autonomous path, ignoring its critics and listening only to its shareholders, to whom it felt somewhat responsible. But the decade of the 1960s was to be a period of enlightenment for many. The Korean War had ended indecisively, and new conflicts in South-East Asia seemed destined to follow the same pattern. Citizens were distrustful of government, business and the undefined "establishment". Consumers had grown suspicious of adulterants in their food and dangerous defects in the products they bought. People were becoming aware of the fragile nature of the earth's ecology, while simultaneously becoming more cognizant of human rights.

The focus, in this paper, is on the largest companies, the transnational corporations (TNCs). By the early 1980s, trade between the 350 largest TNCs contributed about 40 per cent of global trade; today, TNCs account for 70 per cent of the world's trade. Foreign direct investment from TNCs doubled between the early 1980s and the early 1990s, from \$US910 billion to \$US1.7 trillion. Because of their often immense size, decisions about the location of investments, production and technology by TNCs not only influence the distribution of factor endowments, notably of capital, skilled labour and knowledge, between the countries in which they run their activities, but also assume crucial importance for their political and social consequences.

\section{$1.3 \quad$ Today}

We are now seeing consumers avoiding what they see (rightly or wrongly) as socially irresponsible products or the products of companies that have allegedly not acted in society's best interest. Enterprises have noted that social responsibility is good for business for, and from, each of the seven main azimuths within which they trade and operate. These are: their shareholders and potential investors; managers; employees; customers; business partners and contractors or suppliers; the natural environment; and the communities within which they operate, including national governments. Such azimuths are now commonly known as an enterprise's stakeholders.

On the plus side, according to the United States Social Investment Forum, for the first time ever, over \$US1 trillion in assets are under management in the United States in socially and environmentally responsible portfolios. Estimates vary, since much depends on the definitions adopted, but this latter figure has been backed up by The Cerulli Edge-Global Edition, ${ }^{7}$ published by Cerulli Associates, a well-regarded Boston and London-based research consultancy, which in September 2001 estimated the value of the world's ethical investment portfolio to be US $\$ 1.42$ trillion.

${ }^{7}$ Ethical Investor Newsletter, No. 41, 10-16 Sep. 2001, http://www.ethicalinvestor.com.au/ default.asp 
In the United Kingdom, pension fund trustees are required to incorporate their policy on socially responsible investment (SRI) in their statement of investment principles (SIP), the document that sets out the aims, scope and restrictions on the investment of the pension fund. Concomitantly, there has been a rapid expansion of firms that screen companies for socially responsible performance, which is having a positive effect on the redirection of investors toward those companies that are top performers in this area. According to the Ethical Investment Research Service (EIRIS), ${ }^{8}$ about \$US49.3 billion were invested in SRI funds in the United Kingdom in 2001, less than 1 per cent of total funds under management, although this figure has been doubling every two years. Across Europe, about \$US9.38 billion were under SRI management in 2001, again according to the SRI monitoring firm EIRIS.

Pension funds and other financial vehicles have billions of dollars available and speak with a loud voice as their members become increasingly concerned about where and how their money is invested.

Indeed, appalled at being implicated in anti-social practices, thousands of investors are placing ethics on a par with personal gain in choosing where to place their money. In response, a number of money managers are tailoring portfolios to allay their clients' qualms. The managers of billions of dollars of investment funds therefore now channel their cash into companies that pass one test or another for ethical or social responsibility. For people investing their own money, several investment management companies maintain blacklists of ethically or socially irresponsible companies.

Moreover, poor social performance will drive away potential investors. The increase in litigation, especially in the United States (arising from corporate lawbreaking), has strengthened the penalties for professionals and has made the conduct of business a hazardous occupation. Because of the explosion in litigation, business now faces a battle on two fronts: increases in both the number of multimillion dollar verdicts and in the number of actions being filed. Expanded third party liability means that many more professional groups are being held liable, including underwriters, accountants and lawyers. The first year in which substantial awards were accorded to corporate whistle-blowers was 1992. Since then, the increased focus on business conduct has coincided with a growing public perception that business should be more socially responsible.

\section{Different roles}

Where are the boundaries between voluntary CSR initiatives and company "responsibility", and the role of governments in the proper implementation and enforcement of national employment legislation. What are companies responsible for (should the objective be to meet international standards or national law)?

Principles and standards abound to such an extent that companies are puzzling about where to stand. The Global Reporting Initiative (GRI) is currently the industry leader in providing a set of voluntary principles for companies in the area of CSR. Impetus was given to its set of 'voluntary' principles when GRI formally launched its report at the World Summit on

\footnotetext{
${ }^{8}$ Financial Times, Wednesday, 11 July 2001.
} 
Sustainable Development (Johannesburg, August-September 2002). ${ }^{9}$ The list of principles and indicators proposed by the GRI is very weighty, so that companies may start to ask themselves "why bother?" Financial regulation is tough enough, but at least it can help companies to know their main costs and benefits. Social, economic and environmental principles leading to three additional balance sheets seem to be an additional burden, particularly if the benefits are poorly understood, as they are now, and the costs increasing. Consequently, as much as I admire the sentiment behind "triple-bottom line" reporting and see its value as a short-hand formula for introducing the subject of CSR, I much prefer the clearer stakeholder model of reporting presented below in the section on measurement (section 5).

Even as companies struggle with voluntary principles and standards, which critics argue raise the cost of compliance, there is a gradual movement towards regulation. Part of this is coming from the European Union, but various drafts of its papers indicate the struggle within its walls as to whether or not to legislate! Its Green Paper in July 2001 argued:

Corporate social responsibility should nevertheless not be seen as a substitute to regulation or legislation concerning social rights or environmental standards, including the development of new appropriate legislation. In countries where such regulations do not exist, efforts should focus on putting the proper regulatory or legislative framework in place in order to define a level playing field on the basis of which socially responsible practices can be developed. ${ }^{10}$

However, following consultation, the above paragraph was dropped in the Communication published in July 2002. ${ }^{11}$ The European Union even defined CSR to be voluntary when it said:

CSR is a concept whereby companies integrate social and environmental concerns in their business operations and in their interaction with their stakeholders on a voluntary basis. (emphasis added)

In correspondence with one of the authors, I noted that the European Union included process in its definition of CSR through the addition of "on a voluntary basis". I suggested that the word "voluntary" should be eliminated, since you cannot then consider any regulation, however minor. A European Union official, Jürgen Scheftlein, replied that he thought that the definition was obviously a crucial point:

Our compromise was to use again the definition given in the Green Paper, which puts stress on that CSR means going beyond obligations and thus is by nature voluntary. This focus reflects the approach adopted by the Commission, which is not to regulate CSR, but to facilitate the dialogue between the stakeholders on CSR issues and to promote existing market developments. In 2004 we will have more evidence to judge what can be achieved through this approach.

\footnotetext{
${ }^{9}$ see www.globalreporting.org

${ }^{10}$ European Commission, Promoting a European framework for corporate social responsibility, Green Paper, COM(2001)366, 18 July 2001: para. 22.

${ }^{11}$ Commission of the European Communities, Communication from the Commission concerning Corporate Social Responsibility: A business contribution to sustainable Development (COM(2002) 347 final), 2 July 2002.
} 
I much prefer the definition proposed at the very beginning of this paper, which emphasizes more explicitly the stakeholder nature of the concept, while not pre-judging the "voluntary or not" debate.

A pro-regulatory view comes, surprisingly, from companies themselves, or at least some of them, such as BP and the Co-operative Bank in the United Kingdom. They believe that their current behaviour exceeds most existing standards and, of course, they wish to bring other companies, especially their competitors, up to the same level. This process is one that I encapsulated in my book The planetary bargain, ${ }^{12}$ in which I suggest that companies would voluntarily invoke a number of basic principles. They would then "shame and name" rogue companies, thereby encouraging limited legislation. However, the danger of my "minimalist" position, which was essentially to stop a race to the bottom in which companies would jump to favourable countries, has been admirably highlighted by Adrian Henriques, who noted:

The most common reason given for why new legislation would set CSR back is the lowest common denominator argument. This suggests that if there were legislation around CSR, then companies will deliver what the law requires, but never more. At the moment, voluntary CSR is experiencing a hundred flowers in bloom. ${ }^{13}$

What, therefore, are the pluses and minuses of CSR regulation?

\subsection{Pluses of legislation}

- It would help to avoid the excessive exploitation of labour, bribery and corruption.

- Companies would know what is expected of them, thereby promoting a level playing field.

- Many aspects of CSR behaviour are good for business (such as reputation, human resources, branding and making it easier to locate in new communities) and legislation could help to improve profitability, growth and sustainability.

- Some areas, such as downsizing, could help to redress the balance between companies and their employees.

- Rogue companies would find it more difficult to compete through lower standards. The wider community would benefit as companies reach out to the key issue of underdevelopment around the world.

\footnotetext{
${ }^{12}$ Michael Hopkins (1999), The planetary bargain: Corporate social responsibility comes of age, Basingstoke, Macmillan.

${ }^{13}$ Ethical Performance, March 2002
} 
- Additional bureaucracy, with rising costs for observance.

- Costs of operation could rise above those required for continued profitability and sustainability.

- Critics already argue that the CSR of companies is simply to make a profit, and legislation would increase the vocalization of these concerns.

- Reporting criteria vary so much by company, sector and country, and they are in constant evolution.

My own ideas on whether or not to legislate have been evolving over time. My 1998 position argued for a voluntary "planetary bargain" for CSR, or in other words that companies would come to realize that CSR was in their best interests and would "out" rogue companies. More and more companies are already focusing voluntarily on CSR issues, but it is clear, in the light of the poor corporate governance that resulted in both the Enron and World Com debacles, that some further form of legislation is necessary. I now believe that no regulation is out of the question, as is full regulation ... there is ground somewhere between the two. ${ }^{14}$

But the key question remains, who will be the regulator?

- Government? In the United States, the Securities and Exchange Commission is to play an enhanced role, at least as far as something called "corporate responsibility" is concerned. In Europe, the European Union has already stated its position as being on the side of voluntary measures, which will relieve many anti-European Union lobbyists. In all probability, only a few nations will embed CSR principles in national legislation.

- The United Nations? Developing countries would normally look to the United Nations, but we know that the United Nations is not a regulatory body and can only suggest changes for inclusion in national legislation.

- The corporate sector? Like it or not, "voluntary" will be the status quo for the foreseeable future, with only a few companies interested in legislation to create a level playing field. Which means that CSR advocates/consultancies, such as our own (MHCi), will increasingly become the "unacknowledged legislators of mankind" (with apologies to Coleridge, who was referring to poets) in helping companies and governments find their way. And, as The Economist notes: $:^{15}$

If the market comes to admire honesty, transparency and good corporate governance, executives will rush to acquire those characteristics. Even in morality, the market rules - in the end.

${ }^{14}$ Simon Zadek in a reply to my question in an online debate on www.AccountAbility.com, influenced my view on this issue.

15 17-23 Aug. 2002, p. 11. 


\section{The business case for CSR}

Is there a business case for CSR? What are the challenges? Is there an understanding of the impact of CSR on business performance?

Milton Friedman's oft-cited pronouncement that the "social responsibility of business begins and ends with increasing profits" implies that social issues are best left for anyone but business. However, as international organizations, such as the United Nations, its agencies and the World Bank, are having less and less impact on human development and are seeing their funding reduced, and as the pressure increases on governments to spend less and less, the problems of underdevelopment and unemployment refuse to go away. It is logical, therefore, in the absence of public funds, or even in partnership with existing institutions, ${ }^{16}$ that business must play a greater role in human development issues than ever before. In the longer term, richer consumers and improved worldwide income distribution is obviously good for business. But should business be directly involved in these issues, or simply pay taxes and rely on governments and public organizations to use these taxes wisely? In other words, is it simply enough for business to maximize profits in anticipation that this is in the best interests of human development?

It is difficult, in either statistical or quantitative terms, to make a strong causal link between CSR actions and such financial indicators as share prices, market value, return on assets invested and economic value added (EVA). This is because a correlation does not necessarily mean a causal link and a good correlation could simply occur by chance, although no correlation is obviously not a good sign! What most commentators have done up to now is to argue, qualitatively, that there is a business case.$^{17}$ There are at least six main issues:

- First, equity created in a companies reputation or brand can easily be harmed or even lost. This is particularly the case for companies whose brand equity depends on company reputation. Reputation is built around intangibles such as trust, reliability, quality, consistency, credibility, relationships and transparency, and tangibles such as investment in people, diversity and the environment.

- Second, access to financing is an issue since, as will be seen below, the market for socially responsible investment (SRI), though still relatively small, is growing. This increase is a result of the growing support for the business case for CSR, together with regulatory (for example, United Kingdom pension funds), market and societal pressure. These trends are also supported by the creation of new financial indices, such as the FTSE4Good and the Dow Jones Sustainability Index (DJSI), which publicly rank major international companies according to their environmental and social performance.

- Third, CSR is an important factor for employee motivation and in attracting and retaining top quality employees.

\footnotetext{
${ }^{16}$ It is noteworthy that the World Bank has an evolving programme on partnership with the private sector and corporate social responsibility called "Business Partners for Development".

${ }^{17}$ Based on Global corporate citizenship: The leadership challenge for CEOs and boards, Joint statement of a task force of World Economic Forum CEOs and the Prince of Wales International Business Leaders Forum, Geneva (January 2002).
} 
- Fourth, innovation, creativity, intellectual capital and learning are helped by a positive CSR strategy. Given that 80 per cent of the value of many new economy companies is now their intellectual capital, its preservation through the positive treatment of internal stakeholders is becoming more and more necessary.

- Fifth, better risk management can be achieved by in-depth analysis of relations with external stakeholders. Factors such as new technologies and changing societal, regulatory and market expectations are driving companies to adopt a broader perspective when analysing the range of risks that they may encounter. Expensive and time-consuming lawsuits, as well as lost investments, are driving companies to take a more proactive stance to establishing the necessary guidelines and processes to minimize this kind of risk. Given the increase in cross-border business relationships and the threat of cross-border litigation, boards have to consider the risk management standards of business partners, and even suppliers. CSR also helps in compliance with regulation and the avoidance of legal sanctions, while the building of relationships with host governments, communities and other stakeholders can enhance a company's reputation and credibility and be of vital importance should it encounter difficulties in the future with regard to its investment decisions.

- Sixth, there is a wider impact as public expectations grow of greater CSR as a result of the heightened public debate on the benefits and shortcomings of globalization and the perceived role of business in this process. The number of transnational companies has increased from 37,000 in 1990 to over 60,000 today, with the number of foreign affiliates rising to 800,000, compared to about 170,000 in 1990 .

Nevertheless, for each benefit there is a cost. To date there has been, to my knowledge, only one in-depth benefit-cost analysis of CSR in a corporation, namely by the Cooperative Bank in the United Kingdom, which found that between 15 and 18 per cent of its pre-tax profits could be directly attributed to its ethical stance. Such exercises will undoubtedly be more common in the future. The types of items that would need to be included in such exercises are listed in Annex II. ${ }^{18}$

The concept of "corporate citizenship" is parallel to that of CSR (see Annex I for definitions) and Arthur D. Little, reviewing some of the business case for corporate citizenship in a recent publication, notes that good corporate citizenship can provide business benefits in eight areas: ${ }^{19}$

- reputation management;

- risk profile and risk management;

- employee recruitment, motivation and retention;

- investor relations and access to capital;

- learning and innovation;

- competitiveness and market positioning;

\footnotetext{
${ }^{18}$ Source: MHC International, see www.mhcinternational.com

${ }^{19}$ Arthur D. Little (undated), The business case for corporate citizenship, Cambridge, United Kingdom.
} 
- operational efficiency; and

- license to operate.

In discussing each of these areas, the report notes that increased corporate citizenship can improve business performance, reputation and operational efficiency, while reducing risk exposure. Regrettably, empirical analysis is used only sparingly in support of these assertions.

Corporate sustainability is another parallel concept to CSR that has led to a lot of useful work on quantifying the issue of sustainability. This latter concept arose out of concerns for the environment, but has been expanded in recent years to encompass both social and economic aspects of corporations. Some may quibble with the notion of starting from an environmental basis to expand into CSR issues. But, using the imaginative title of Buried treasure, the United Nations Environment Programme (UNEP) and the consulting firm SustainAbility have produced an original piece of work that matches the traditional indicators of business performance against sustainable development performance. ${ }^{20}$ Ten measures of business performance are used (the dependent or endogenous variables), namely: (1) shareholder value; (2) revenue; (3) operational efficiency; (4) access to capital; (5) customer attraction; (6) brand value and reputation; (7) human and intellectual capital, (8) risk profile; (9) innovation; and (10) licence to operate. These are then related, in a matrix, to ten driver dimensions (exogenous variables), namely: (a) ethics, values and principles; (b) accountability and transparency; (c) triple bottom line commitment; (d) environmental process focus; (e) environmental product focus; (f) socio-economic development; (g) human rights; (h) workplace conditions; (i) engaging business partners; and $(\mathrm{j})$ engaging non-business partners. The results are presented, imaginatively, in matrix format using colour-coding which, nevertheless, may be somewhat confusing.

In a similar vein, the World Business Council for Sustainable Development (WBCSD) has produced a pamphlet, The business case for sustainable development. ${ }^{21}$ However, the pamphlet only cites one piece of evidence in making its case:

During the five years before August 2001 the Dow Jones Sustainability Index (DJSI) clearly outperformed the Dow Jones Global Index (DJGI). While the DJSI had an annualized return of $15.8 \%$, the DJGI increased by $12.5 \%$ in that period. The DJSI consists of the top 10 per cent of companies in 68 industry groups in 21 countries seen as leaders in sustainable development.

Unfortunately, as in the saying "one swallow does not a summer make", such a selection is not representative of all companies trying to be "sustainable" (in the environmental sense). As I have noted elsewhere: ${ }^{22}$

\footnotetext{
20 SustainAbility/UNEP: Buried treasure: Uncovering the business case for corporate sustainability, UNEP, Paris, 2001.

${ }^{21}$ WBCSD, (Sep. 2001), The business case for sustainable development: Making a difference toward the Johannesburg Summit 2002 and beyond. Geneva, www.wbcsd.org

${ }^{22}$ Michael Hopkins, “CSR Investment: The next 'dot.com' boom but without the crash”, Nov. 2001, Monthly Feature, www.mhcinternational.com; and Michael Hopkins: "The business case for CSR: Where are we?", in International Journal for Business Performance, 5(2/3), 2003, pp. 125-140.
} 
(...) the Canadian Jantsi social investment index (JSI) from its inception on 1 January 2000 through 31 August 2001, lost 12.47 per cent, while the Canadian S\&P /TSE 60 and the TSE 300 lost 12.11 per cent and 10.69 per cent, respectively, over the same period.

Hardly an impressive result, when even income bonds were providing a positive, albeit modest, return of between 2 and 3 per cent. Clearly, more exhaustive and statistically representative research is required.

\section{Benchmarks used by companies}

What are the benchmarks that are being used by companies for the establishment of private initiatives (for example, the ILO Declaration or core Conventions, United Nations Declarations)? What are the limitations to such an approach? What is the role for the ILO Declaration, international labour standards and other international benchmarks?

No absolute benchmarks exist in the world of CSR. Some companies are often cited as the role models - the Body Shop was one of the first. Subsequently, a number of well-known companies, such as Shell and British Telecom, led the way, while smaller companies, including Van City (a Canadian Bank) and the Co-operative Bank (United Kingdom), have become role models. On the other hand, there are literally hundreds of codes of conduct and principles around the world. These codes are proliferating, but rarely if ever situate themselves within what has happened before or specify why the new code is different or an advance on previous codes. Few, if any, have a theoretical basis for their codes, while many simply cover just one or at most two stakeholders. There is a serious need for rationalization if companies are not to become even more confused than they are now about what is expected of them.

The codes, conventions, principles and standards available have as their aim some aspect of improving the behaviour of corporations, and more appear to be emerging every day. An OECD report identifies [233] codes of practice ${ }^{23}$ and an ILO report several hundred. ${ }^{24}$ Some of the best known are listed in Annex III, where they are categorized into four main types of initiative: governmental and intergovernmental initiatives; company-led; NGOled; governance.

The case for the endorsement of codes stems from the need to: ${ }^{25}$

- protect and enhance a company's reputation;

- establish the management's commitment to sound ethical behaviour;

${ }^{23}$ See http://www.oecd.org/dataoecd/57/24/1922656.pdf OECD, Codes of corporate conduct: Expanded review of their contents, Directorate for Financial, Fiscal and Enterprise Affairs, Working Papaers on International investment No. 2001/6, Paris, May 2001.

${ }^{24}$ Michael Urminsky (ed.), Self-regulation in the workplace: Codes of conduct, social labeling and socially responsible investment, Series on Management Systems and Corporate Citizenship. MCC Working Paper No. 1, Geneva, ILO.

${ }^{25}$ Based on the 2001 survey by the Conference Board (United States) of around 100 large companies. 
- raise stakeholder confidence;

- demonstrate corporate prevention rather than response to crises; and

- acknowledge corporate peer pressure for higher standards of accountability and transparency .

The case against the endorsement of codes is:

- code proliferation is a counter-productive distraction that should be ignored;

- there is no unique, unchangeable and widely accepted code;

- codes do not take into account the running of a company and its major concerns to stay alive and avoid takeover or bankruptcy; and

- codes may lead to third party certification that is costly and without added value.

\subsection{Overview of the content of codes}

Codes vary according to the areas that they cover. The OECD report categorizes five main areas of conduct: (a) fair business practices; (b) observance of the rule of law; (c) fair employment and labour rights; (d) environmental stewardship; and (e) corporate citizenship. ${ }^{26}$ Codes also vary according to the sponsoring organization or partnership. According to a report by the United States Council for International Business (USCIB), ${ }^{27}$ most existing codes have been developed by individual companies for use in their own operations and management.

The ILO report by Michael Urminsky ${ }^{28}$ defines "code of conduct" as: "a written policy, or statement of principles, intended to serve as the basis for a commitment to particular enterprise conduct." In his study of 258 codes, Urminsky found that 67 per cent were devised by enterprises themselves, 11 per cent by enterprise associations, 7 per cent by NGOs, 8 per cent by framework agreement (whatever that means), 3.5 per cent by workers' organizations and only 0.4 per cent by governmental bodies. Of the codes examined, only 20 ( 8 per cent) include any statement regarding a commitment to communicating the code, and only 6 per cent are interested in external monitoring or inspection.

Most, if not all codes are voluntary and few require formal and independent verification when used by companies. Their coverage is uneven. Some set forth principles of overall behaviour (OECD, European Union and ILO codes for multinational enterprises); some refer to one stakeholder, such as management (corporate codes of governance, such as the

\footnotetext{
${ }^{26}$ OECD, 2001, op. cit.

27 USCIB Corporate Responsibility Committee (2002), USCIB Compendium of Corporate Responsibility Initiatives, United States Council for International Business.

${ }^{28}$ Urminsky, op. cit, p. 13.
} 
King Commonwealth Report, ${ }^{29}$ the Turnbull Report ${ }^{30}$ in the United Kingdom, President Bush's Ten-Point Plan to Improve Corporate Responsibility and Protect America's Shareholders, the environment (the CERES principles, the UNEP Financial Statement) or labour (SA8000, ICFTU Codes of Labour Practice, the ILO's Tripartite declaration of Principles concerning Multinational Enterprises and Social Policy, the Fair Labor Association Workplace Code of Conduct, the Ethical Trading Initiative Base Code). Some refer to one or more stakeholders (the United States Model Business Practices cover labour and the environment), the United Nations Global Compact relates to labour, human rights and the environment, the Global Sullivan Principles refer to external stakeholders, while others, particularly some of the more recent, cover most if not all stakeholders in a firm (GRI, AAIOOOs, Social Venture Network Standards of CSR). As the USCIB notes:

The trend toward multi-issue codes has led to the development of substantially identical codes that vary only in sponsoring organizations and/or geographic representation. Recent examples indicate that geography plays a key role in such cases. ${ }^{3}$

Annex III groups some of the main codes. Their concentration in Brussels, Geneva, London, Paris, New York and Washington DC is striking

\subsection{Recent prominent codes}

Four prominent codes of conduct (following Urminsky's definition referred to above) are the GRI, AlOOO, SA8000 and the United Nations Global Compact. The GRI is intended to help companies produce social reports and, as its most recent report states, "the Guidelines themselves are not a code of conduct nor a performance standard". ${ }^{32}$

One can only therefore wonder what they are?

Denial is also associated with the United Kingdom NGO AccountAbility IOOOs AA1000 series, ${ }^{33}$ which is associated with GRI: "the Guidelines can be used in conjunction with emerging approaches to standardized reporting such as the $\mathrm{GR}^{34}$ but then assure themselves that they are really process-orientated" (to what? Certainly a code of best practice) when they say in the same document:

Assurance is an evaluation against a specified set of principles and standards of the quality of specified public reports and the systems, processes and competencies that deliver the associated information and underpin the reporting organisation's performance.

\footnotetext{
${ }^{29}$ Institute of Directors in Southern Africa, King report on corporate governance for South Africa, 2002 (King II Report), Mrch 2002.

${ }^{30}$ Institute of Chartered Accountants in England and Wales, 1999, Internal control: Guidance for directors on the Combined Code (the Turnbull Report), London, Accountancy Books.

${ }^{31}$ USCIB, op. cit., page 6.

${ }^{32}$ Reference: http://www.globalreporting.org/guidelines/2002/gri_companion_lite.pdf, page 3

${ }^{33}$ See http://www.accountability.org.uk/

${ }^{34}$ Ibid.
} 
SA $8000^{35}$ and the United Nations Global Compact ${ }^{36}$ admit to setting standards for company behaviour, the former for the labour stakeholder group and the latter for three stakeholder groups: labour, environment and the community (human rights).

Of these four codes, only the first two purport to be multi-stakeholder, while the other two are limited to a selection of stakeholders. There is no doubt that, of these codes, the Global Reporting Initiative is currently the most wide-ranging. It has been brave enough to attempt to devise a set of indicators, so that companies can report on the progress made in meeting "triple bottom line" objectives. However, it is not without its critics. ${ }^{37}$ Deloitte and Touche have stated: ${ }^{38}$

We do believe that the core indicators required by the 2002 Exposure Draft are too voluminous and will discourage too many organizations from even attempting to report under the GRI guidelines. Further, we believe that the required boundaries of a sustainability report should not exceed the reporting entity's circle of control because it is unlikely that the reporting entity would have the ability to obtain the requisite information or determine its accuracy. Management may present supplementary, or additional, information on such matters, where relevant. We are concerned that the GRI is proceeding down a path of attempting to make a sustainability report be everything to everyone rather than focusing on how the reporting entity's sustainability performance can be measured overall. While we recognise that the latter form of a sustainability report will not suit each and every stakeholder's perceived needs, we believe it will result in a far more meaningful presentation.

Nike, too, was critical, but appreciated GRI's flexibility:

The depth of the questions is overwhelming at times, however the flexibility allowed by the structure makes the GRI more digestible and tenable than most surveys. It can also serve as a useful catalyst in engaging internal leaders in substantive discussion around governance and triple bottom line accountabilities. ${ }^{39}$

\subsection{Conceptual difficulties}

One of the biggest problems faced by devisers of codes of conduct or principles of behaviour is what conceptual basis to use. There is a proliferation of terms, including CSR, corporate citizenship, corporate sustainability and business ethics. ${ }^{40}$ I obviously prefer my definition of CSR, cited above. Others tend to include confusing terms, such as "sustainability" or "triple bottom line". Moreover, the conceptual basis is often poor, as I show briefly with the triple bottom line approach outlined below.

\footnotetext{
${ }^{35}$ See www.cepaa.org

${ }^{36}$ See www.unglobalcompact.org

${ }^{37}$ See for instance, The Global Reporting Initiative: Raising the bar too high?, by Mallen Baker, Aug. 2002, www.mallenbaker.net

${ }^{38}$ See, http://www.mallenbaker.net/csr/nl/index.html Business Respect, 38(8), September 2002.

${ }^{39}$ Ibid.

${ }^{40}$ See a glossary of such terms on www.mhcinternational.com/glossary.htm
} 
A useful framework for analysing codes of conduct has been developed by Donna Wood, for which I have established a number of indicators (see the next section). It is also a multistakeholder concept. ${ }^{41}$ This conceptual model raises the questions of whether a company has a clear statement of principles, whether it is followed up by a number of processes for its implementation and what outputs can be measured. CSR is therefore measured on the basis of the configuration of the business organization into three levels, or the Triple- $P$ approach to CSR:

- Principles of social responsibility;

- Processes of social responsiveness;

- Products (or outcomes) as they relate to the firm's societal relationships.

These can then naturally be further divided into the principles, processes and outcomes for each stakeholder group.

In practice, GRI implicitly uses this approach, but gets a little confused by jumping into the triple bottom line bed. That latter notion was developed by John Elkington in his book Cannibals with forks ${ }^{42}$ describing his own progression from the environmental field into the wider fields of social and economic considerations. Given that GRI took its first steps in the environmental field, as it grew out of the CERES environmental principles, it is not surprising that it is a little hamstrung by environmental considerations.

The triple bottom line approach (TBL) is simply too confusing and intellectually suspect as a basis for a code of conduct. The initial attraction, of course, is that TBL appears to introduce concerns relating to the environment and society neatly alongside the usual business notions of profitability (the economic bottom line). However, the TBL concept suffers from at least four main difficulties:

1. Companies cannot simply put profitability on the same level as social and environmental considerations, as a company cannot survive by behaving in a socially or environmentally responsible manner while making losses.

2. Social and environmental benefits tend to be long-term before impacting on stakeholder value.

3. TBL equates social with environmental, whereas social clearly encompasses environmental as one among many other concerns.

4. The notion of stakeholder is not necessarily defined in the TBL approach.

Therefore, let corporations focus on creating stakeholder value as measured by profits, but in a socially responsible manner. Let us not add on a "surplus less deficit" approach based on environmental or social considerations. A company that does poorly on one line, namely profits, but wonderfully on the environment or social component of TBL, is not going to last long in a competitive world! So let us abandon that approach and concentrate

\footnotetext{
${ }^{41}$ For a fuller description, see www.mhcinternational.com/measurement.htm

42 John Elkington (1998), Cannibals with forks: The triple bottom line of $21^{\text {st }}$ century business, New Society Publishers.
} 
on defining exactly what is meant by a corporation's responsibility to its stakeholders, who they are and how to measure progress through a limited number of precise key indicators. ${ }^{43}$

\subsection{The ILO?}

The idea of relating improved labour conditions to trade is not new. At the international level, this has come under the heading of a social clause. Discussions on the inclusion of a social clause in international agreements have also been under way for many decades. The intention is to help promote fair competition between developing country exporters by ensuring that those which respect minimum labour standards are not penalized for their efforts to promote human development.

Progress towards the inclusion of a social clause in effective international agreements has been painfully slow. This is because some developing countries feel that the concern of industrialized countries in relation to working conditions is due above all to their export success and the growing pressure for protectionism that has arisen as a result of high unemployment. A social clause is seen as a disguised form of protectionism, a Trojan horse that is tantamount to interference in their internal affairs, through which they are being asked for reciprocity in social obligations in return for trade concessions. The private sector sees it as yet another restriction on its ability to provide the best quality products at the lowest possible prices.

Any negotiation at the international level therefore has to be handled carefully, with the benefits and costs for both industrialized and developing countries being clearly spelled out. This is something that neither the WTO, with its limited staff and research capability, nor the ILO, which finds it politically very difficult to support research and analysis of its labour standards, have accomplished to date. And the question of whether the agreement should be voluntary, because it is in everyone's best interests, or regulatory, is deserving of further reflection. On this latter point, it is worth mentioning that, since its establishment in 1919, the ILO has not achieved the passage of any of its Conventions or Recommendations on labour standards into any form of international law. Many countries have, however, included ILO labour standards in their national laws. Nevertheless, there is no international obligation on countries to do so.

Attempts were made to include a linkage between a social clause and trade in the Uruguay Round of GATT, which pre-dated the WTO. But this was rejected and only faltering attempts have been made in this direction in the relatively new WTO. Given the importance of this matter, it is somewhat surprising that progress at the international level has been so slow. There were no provisions in GATT to ensure that an improved social clause was pursued, nor are there in its successor, the WTO. The ILO, which is responsible for ensuring the application of labour standards, has been slow, and even ignored, in its championing of this cause in international discussions.

${ }^{43}$ Further references on this topic are: (1) Michael Kane (2002), Resources for promoting global business principles and best practices: A directory of people, organizations and web sites, United States Government, Environmental Protection Agency, Washington, DC, updated regularly, contact: kane.Michael@epa.gov; (2) USCIB, op. cit.; (3) Holly J. Gregory, International comparison of corporate governance guidelines and codes of best practice in developed markets, (2001 edition) Weil, Gotshal \& Manges LLP, New York; (4) Business for Social Responsibility (2000), Comparison of selected social responsibility related standards. 
The ILO has, however, been active in producing labour standards through its Conventions and Recommendations, and as of December 2003 there were 185 Conventions and 194 Recommendations. Yet it appears to be more active in creating new instruments, thereby spreading itself too thinly, than in conducting research on the impact and value of its labour standards, although it has now gone some way in identifying a minimum set of standards that could be included in a social clause or a social agreement through the adoption in 1998 of the Declaration on Fundamental Principles and Rights at Work. The standards involved are those on freedom of association, the right to organize and collective bargaining, the minimum age for the employment of young persons and freedom from discrimination in employment and from forced labour. But, as Gijsbert van Liemt, one of its former analysts, has noted, "the ILO Constitution gives no indication of priorities for the application of international labour standards", adding that the wide range of areas covered "would make it impossible - particularly in developing countries with their weak administrative machinery - to expect most or even many of them to be implemented."

Moreover, the emphasis is not so much on economic as legislative aspects. Economic aspects would include such matters as social protection, pensions and health insurance, all of which could stimulate effective demand for new products. Indeed, a weakness of ILO policy advice is that it normally raises the cost of labour and hardly ever considers the economic benefits to the institution that has to pay the increased charges. This is not a point taken lightly, since few would question the desire to implement many, if not all, of the ILO's social policy standards. What is not done is to prioritize social policy in terms of what is essential and what is affordable. The core labour standards approach, which has been picked up in the Global Compact, is a step in the direction of prioritizing, but on political rather than on economic grounds.

A recent OECD study, International trade and core labour standards,${ }^{45}$ backed up some of these statements when it noted that:

there remains a continuing gap between the international recognition of core labour standards and their application. Based on published observations of the ILO Committee of Experts on the Application of Conventions and Recommendations, the OECD study finds no indication in recent years of substantial progress overall in reducing non-compliance with respect to freedom of association and the right to collective bargaining among a broad sample of 69 countries that have ratified the two corresponding ILO fundamental conventions. ${ }^{46}$

The same OECD report noted that the WTO members in their December 1996 Ministerial Meeting in Singapore rejected the use of labour standards, which they considered to be protectionist, and in classic United Nations prose "recognized" the ILO as the "competent body to set and deal with" core labour standards. This may be translated as, "we do not want to deal with this controversial issue, let the ILO deal with it". Hiding the problem under the carpet in this way gives legitimate cause for concern to critics of the WTO and to at least some of the active demonstrators known, mistakenly, as anti-globalization protestors.

\footnotetext{
${ }^{44}$ Gijsbert van Liemt, "Minimum labour standards and international trade: Would a social clause work?”, in International Labour Review, 128(4), 1989, pp. 433-448.

${ }^{45}$ OECD (2000), International trade and core labour standards, Paris.

${ }^{46}$ OECD (2000), "International trade and core labour standards", Policy Brief, in OECD Observer, Paris, October, p. 2.
} 
At the Third WTO Ministerial Conference in Seattle in December 1999, proposals by the United States, Canada and the European Union to set up a WTO working group on the relationship between appropriate trade, developmental, social and environmental policy choices in the context of adjusting to globalization were rejected!

However, as noted above, there is some light at the end of the tunnel, as the ILO, together with the OECD, has moved towards adopting a "core" set of labour standards. These follow the list applied in much United States trade legislation:

- freedom of association;

- the right to organize and bargain collectively;

- the prohibition of forced or compulsory labour;

- a minimum age for the employment of children; and

- a guarantee of acceptable working conditions (possibly including a maximum number of hours per week, a weekly rest period, limits to work by young persons, a minimum wage, minimum workplace safety and health standards and the elimination of discrimination in employment).

As Stephen Golub remarked, this list blends labour "rights", such as freedom of association, with regulations on working conditions and wages, which are economic in nature. The OECD/ILO's core list is similar to that of the United States, except that the fifth is limited to the elimination of discrimination in employment.

In 1997, the ILO Director-General put his weight and that of his Organization behind this core set of standards, as has his successor, Juan Somavia, although the language has been guarded:

[A]lthough it is up to each member State to decide upon the areas and social priorities which should benefit from the fruits of growth and prosperity generated by globalization, there is nevertheless a 'minimum programme' that each should try to achieve. ${ }^{47}$

A social clause could go further than just trade. It could also be linked to public capital flows, such as official loans and aid, and to strategic relations, such as defence treaties. After all, countries spend billions of dollars on their defence industries, largely to prevent the have-nots from obtaining access to what is possessed by the haves. Efforts that go into raising living standards through a social clause are likely to have much higher pay-offs in terms of peace than the encouragement of, and therefore the need for expensive armies.

There have been several other attempts to establish a social clause at the international level, but these have so far resulted in failure. For example, the European Commission endeavoured to include a social clause with the African, Caribbean and Pacific countries covered by its Lomé Convention. But the Convention, signed in 1975, refers only to respect for human rights, without a follow-up or control mechanism. Similarly, a number

47 The ILO, standard setting and globalization, International Labour Conference, Report of the Director-General, 85th Session, 1997, p. 24. 
of international commodity agreements contain a social clause. For example, the 1979 Natural Rubber Agreement states that its members will endeavour to maintain labour standards designed to improve the levels of living in their respective natural rubber sectors, but there is no monitoring, control or legal provision to ensure observance.

Evidence is already accumulating that a planetary bargain or global compact that goes much further than the United Nations so-called Global Compact is required. Companies that have already blazed a green path over the past five years in the United Kingdom want (according to John Elkington, Chairman of SustainAbility, in a report published with UNEP) to see dramatic progress in reporting on emissions, spending and social impacts in general. Elkington predicted an explosion of activity over the next few years, even without mandatory requirements, as demands for greater transparency force more companies to report beyond their traditional financial boundaries. ${ }^{48}$ Already, several hundred companies have signed up to the United Nations Global Compact. However, all of these companies have ignored or skated over the question of a more wide-ranging global compact than that of the United Nations and how it could be set in motion. Clearly, more thinking must be undertaken on precisely what kinds of measures should be put into place, by whom and when. Although the United Nations Global Compact has set up a number of working groups to develop some of these issues, to date it lacks the financial resources and in-depth analytical work to progress very far.

What, then, could a planetary bargain or global compact contain, and to whom should it be directed? There are three main criteria:

- At the international level, there is a case for vigorously pursuing a minimum priority set of labour standards and social protection for inclusion in international agreements in the WTO.

- Private companies should be encouraged to work towards a set of minimum working conditions that all will respect. This could be accomplished through such bodies as the United Nations, ILO, OECD and the European Union, and it is in the private sector's own interest to do this. The leading figures in the major companies of the world should be brought together to thrash out a first agreement.

- Individual nations should work actively to agree upon and respect a minimum code of ethics for their trade with other nations.

Since the first edition of this paper, there have been a number of moves to require companies to adhere to a set of global principles, such as the Global Reporting Initiative, the United Nations Global Compact, AA1000 and the OECD Principles of Corporate Governance. Some companies have indicated their willingness to abide by such principles, and even to be subject to sanctions for non-compliance. This is because they would be willing to accept a "level playing field", to which their main competitors would also adhere. Legislation is difficult, since implementation of a code by one country would punish those companies headquartered there to the benefit of companies with headquarters elsewhere, for example in the Cayman Islands, Netherlands Antilles or Panama, where poor levels of corporate governance are legendary. Such a code could not be a once-andfor-all negotiation to produce a global guideline, as society changes too fast. What is envisaged is a continuing process of dialogue between governments and enterprises.

${ }^{48}$ Elkington, 1998, op. cit. 
Who should represent both sides? In practice, such a process has already started in international organizations, as noted above, through the OECD's corporate governance forums, the World Bank's business partnership and corporate governance discussions, the United Nations Global Compact, the UNEP sustainability dimension, the Global Reporting Initiative and the ILO's tripartite conferences and meetings, which bring together representatives of employers, trade unions and governments.

Who should represent enterprises? This is more problematical. At the ILO, where enterprises have been represented for generations, normally by chambers of commerce, large corporations rarely show up. The United Nations Global Compact has had more success, and the ILO is represented, but the agenda, as noted above, has so far been limited to a few stakeholders. Nevertheless, enterprises are active in a variety of NGO settings, such as Business for Social Responsibility (BSR), the European Business Network for Social Cohesion (EBNSC), the World Business Council for Sustainable Development (WBCSD) and the International Chamber of Commerce (ICC). Yet, in each case, the agenda is different and the concepts are vague.

What about other stakeholder groups, such as trade unions, consumers, non-unionized workers, distributors, retailers, suppliers and shareholders? Up to now, no single body has involved all these groups, as well as governments and enterprises. The nearest organization is the ILO, but the debates there are intensely political and the ILO has found it nearly impossible to implement even one specific area of corporate social responsibility, that of a core set of labour standards.

\section{Measurement systems}

What measurement systems are companies using to assess the impact of such initiatives?

There is no agreed measurement system for CSR, although companies such as Shell have tried through its Key Performance Indicators (KPI), and GRI has also been active in this area. But there is no single methodological framework in existence which has achieved widespread agreement. The nearest might well be the framework first developed in the United States by Prof. Donna Wood, which I have adapted and applied to dozens of companies. This framework is based on three levels, as described above, namely: the principles of social responsibility, the processes of social responsiveness and the outcomes as they relate to the firm's societal relationships (see section 4.3). ${ }^{49}$

The following sections examine each of these levels in turn.

\footnotetext{
${ }^{49}$ For a fuller description see www.mhcinternational.com/measurement.htm
} 


\subsection{Level I: Principles of social responsibility}

The level of application of these principles is institutional and is based on a firm's basic obligations as a business organization. The value of this level is that it defines the institutional relationship between business and society at large, and specifies what is expected of any business. It has three major elements:

- Legitimacy concerns business as a social institution, and frames the analytical view of the inter-relationship between business and society;

- Public responsibility concerns the individual firm and its processes and outcomes within the framework of its own principles in terms of what it actually does;

- Managerial discretion whereby managers and other organizational members are moral actors. Within every domain of corporate social responsibility, they are obliged to exercise such discretion as is available to them towards socially responsible outcomes.

\subsection{Level II: Processes of social responsibility}

Corporate social responsiveness consists of the capacity of a business to respond to social pressures. This suggests the ability of a business organization to survive through adaptation to its business environment. To do so, it must know as much as possible about the business environment, be capable of analysing the relevant data and must react to the results of this analysis. But the environment of a business is not static; it is a complex and ever changing set of circumstances. This environment can be unchanged for decades, if not centuries, and then it falls apart and is reformed like a kaleidoscope with increasing rapidity. The ability to scan, interpret and react successfully to the business environment requires equally complex mechanisms.

Three elements are identified as being basic to this level of the CSR model:

- Business environment scanning indicates the informational gathering arm of the business and the transmission of the information gathered throughout the organization.

- Stakeholder management. A stakeholder is defined as any group or individual which can affect or is affected by the achievement of the firm's objectives, such as owners, suppliers, employees, customers, competitors, domestic and foreign governments, non-profit organizations and environmental and consumer protection groups. Stakeholder management refers to mapping the relationships of stakeholders to the firm (and among each other) whilst finding, listening and meeting their expectations that legitimate concerns should be balanced and met as a prerequisite for any measurement process.

- Issues management. Having identified the motivating principles of a firm and determined the identities, relationships and power of stakeholders, the researcher now turns to the main issues which concern stakeholders. 
The main focus of measurement is the third level of the CSR model. To determine whether "CSR makes a difference", all of the stakeholders relevant to an issue or complex of issues must be included in any assessment of performance. There are, again, three main categories:

- Internal stakeholder effects are those that affect stakeholders within the firm. An examination of these might show how a corporate code of ethics affects the day-today decision making of the firm with reference to social responsibility. It may also be concerned with human resource policies, such as the positive or negative effects of corporate hiring and employee benefits practices.

- External stakeholder effects concern the impact of corporate actions on persons or groups outside the firm. They may involve, for example, the negative effects of a product recall, the positive effects of community-related corporate philanthropy or, assuming that the natural environment is a stakeholder, the effects of toxic waste disposal.

- External institutional effects refer to the effects upon the larger institution of business, rather than on any particular stakeholder group. For example, several environmental disasters have made the public aware of the effect of business decisions on the general public. This new awareness has brought about pressure for environmental regulation, which has then affected the entire institution of business, rather than one specific firm.

\title{
5.4 Applying the measurement CSR model: An example
}

An example of the way in which the model might be applied is given for Ben \& Jerry's Homemade Ice Cream. Ben \& Jerry's founder, Ben Cohen, explained one aspect of the ethical principles of the firm.

\begin{abstract}
Businesses tend to exploit communities and their workers, and that wasn't the way I thought the game should be played. I thought it should be the opposite - that business had a responsibility to give back to the community, that is because the business is allowed to be there in the first place, the business ought to support the community. What we're finding is that when you support the community, the community supports you back.
\end{abstract}

This is a clear statement of principles which belongs in the first level of the CSR model. As stated, the principle fulfils the institutional element (it acts to legitimize the institution of business), the discretionary element (it directs the firm in a socially responsible path) and, in going well beyond any legal requirements, the element of public responsibility. 
At the level of processes of social responsiveness, corporate social responsiveness consists of the capacity of a business to respond to social pressures. Ben \& Jerry's scanning of social issues is accomplished through a number of mechanisms, ranging from direct community involvement through newsletters to special events sponsored by the company. The effectiveness of the scanning and issues management mechanisms can be seen in Ben \& Jerry's funding of organizations as diverse as the Native American Community Board in South Dakota and the Central Massachusetts Safe Energy Project. Clear linkages can be seen between Ben Cohen's principles, as stated, and concrete corporate action.

Among the hundreds of issues raised by Ben \& Jerry's, one specific outcome was achieved through its purchasing policies. To bake its brownies, the firm turned to the Greystone Bakery in Yonkers, New York, a firm which uses its profits to house the homeless and train them as bakers. This outcome is very specific and wholly measurable in a number of ways. The number of homeless people employed by the bakery and the number of trained bakers graduated by the programme could simply be measured. Or the numbers that are still employed at the bakery or in another company as bakers could be examined.

There is a clear causal linkage back through corporate mechanisms to ethical principles and the analytical framework can be seen to function. Further research could be done at Ben \& Jerry's to cross-relate different elements and their indicators to determine how, for example, profitability is affected by the 7.5 per cent share of pre-tax earnings given by Ben \& Jerry's to philanthropic purposes. Conversely, a proposed indicator, such as "outcomes of community involvement" might be taken and its statistical relationships to other indicators in other elements examined.

The first stakeholders in this process are external to the company and are the homeless who take part in the training programme. A second group of stakeholders can be identified as the community from which the homeless are taken. Clearly, the bakery itself profits as a supplier to Ben \& Jerry's and in turn provides benefits to the stakeholders, which are possible because of its business with Ben \& Jerry's. As one aspect of a very successful social programme, this also benefits shareholders as the success of the firm grows. This is a classic case of new avenues of thinking leading to better profits, reputation and employment, as well as a real improvement in the quality of life in the society in which Ben and Jerry's are operating.

\subsection{What indicators do I use?}

These are presented in a table too detailed to include here. However, they can be examined on my web site. Further, a subset of these indicators have been framed into 20 questions that can allow companies, institutions and NGOs, for example, to self-rate their own $\mathrm{CSR}^{50}$

\footnotetext{
${ }^{50}$ http://www.mhcinternational.com
} 


\section{Role of international organizations ${ }^{51}$}

Is there a role for the multilateral agencies, such as the ILO, in establishing guidelines for good practice in terms of the possible content or design and implementation process of private initiatives?

Many efforts are being undertaken worldwide by corporations, governments, international organizations, consulting firms and NGOs. The challenges, of course, include such issues as research, training, comprehension of concepts and implementation, to name but a few. But perhaps the main challenge is to fill gaps through research in two main areas:

- What is CSR all about?

- Why should corporations, governments, NGOs and civil society bother about CSR and, if they do, what is in it for them?

On the first issue, as noted earlier, the conceptual basis needs to be examined seriously. What I am talking about is the sort of effort that the ILO, for instance, has put into defining what is meant by employment and unemployment. What term should we use? Corporate sustainability? Corporate social responsibility? Corporate citizenship? Business in society?

The second closely related issue is what does CSR mean for a company's bottom line? Only when concepts are clear can the components and indicators be developed that are required for the measurement of progress on CSR and then a decision taken as to what indicators should be included in a company's bottom line? Of course, indicators are only the first step. It is then necessary to find data to give weight to these two sets of indicators. The GRI, for instance, has made a step in this direction, ${ }^{52}$ particularly through its attempt to develop a core set of indicators that are also measurable. It is then also necessary to identify how causation from CSR performance can be related to a company's bottom line. ${ }^{53}$

The following issues are related to the above two key challenges.

\section{Internal stakeholders}

- Who are the key stakeholders of a firm (for example, the internal ones could be managers, employees, shareholders, executive directors and non-executive directors)?

- How can stakeholders be identified?

- What elements should be included in stakeholder dialogues?

\footnotetext{
${ }^{51}$ This section has been drawn from Michael Hopkins "Sustainability in the internal operations of companies", presented at the United Nations Global Compact Conference, New York, February 2002 and published in Corporate Environmental Strategy, December 2002, 9(4), pp. 398-408.

${ }^{52}$ See www.globalreporting.org

${ }^{53}$ Note that successful companies sometimes give greater weight to CSR simply because they can afford to, hence correlation does not necessarily mean causation.
} 


\section{Standards}

- Are standardized and certified management systems helping?

- How can their impact be improved?

- Which ones are the most current?

- Who should set the rules of the game?

- Should partners in setting the rules of the game include NGOs, governments, private sector representatives?

\section{Corporate culture}

- What is the value and relevance of labour, human rights and the environment to core business operations?

\section{Corporate governance}

- How do ethics, values and principles make a difference?

- What are the main corporate governance issues that should be revised?

\section{Sustainability/social reporting}

- How does sustainability reporting help the company to improve its management systems?

- Is sustainability reporting the same as social reporting?

\section{Business performance}

- How does improved CSR performance, in terms of process and products, affect a business' bottom line?

- How does CSR affect the company's brand value and reputation?

- How can the related benefits be measured?

- Where are we in measuring intangible assets? 


\section{Next steps for the ILO}

Finally, what particular next steps could the ILO take? I suggest that it should:

1. Put the same effort that has been made in developing ILO statistical definitions into defining the key components of CSR. Companies (like countries today) will use ILO definitions for ever more.

2. As in its collaboration with the United Nations Global Compact, ensure that the ILO's core labour standards for countries are translated into meaningful standards for companies.

3. Explore the application of these standards through empirical application and case studies.

4. Continue research into codes of conduct in the light of their application, while ensuring that labour costs do not spiral out of control.

5. Continue to serve as a forum between governments, enterprises and unions and, more particularly, on the issue of a planetary bargain for companies. 


\section{Box 1 \\ Glossary of Terms}

- Corporate social responsibility is concerned with treating the stakeholders of the firm ethically or in a responsible manner. "Ethically or responsible" means treating stakeholders in a manner deemed acceptable in civilized societies. Social includes economic responsibility. Stakeholders exist both within a firm and outside - the natural environment is a stakeholder for example. The wider aim of social responsibility is to create higher and higher standards of living, while preserving the profitability of the corporation, for peoples both within and outside the corporation (Michael Hopkins).

- Corporate citizenship implies a strategy that moves from a focus on short-term transaction to longer term, values-based relationships with these stakeholders. Loyalty will be based on a company's ability to build a sense of shared values and mission with key stakeholders (S. Zadek et al., The civil corporation: The new economy of corporate citizenship, London, Earthscan, 2001).

- A socially responsible company will seek and identify the concerns of its stakeholders and endeavour to treat those stakeholders fairly. (Stephanie Draper, Corporate Nirvana: Is the future socially responsible?, London, Industrial Society, 2000).

- Corporate social responsiveness is the management task of doing what one has decided to do so as to become socially responsible (Ackerman and Bauer, 1976, op. cit.).

- Corporate governance is concerned with holding the balance between economic and social goals and between individual and communal goals. The governance framework is there to encourage the efficient use of resources and equally to require accountability for the stewardship of those resources. The aim is to align as nearly as possible the interests of individuals, corporations and society" (Sir Adrian Cadbury, in Global Corporate Governance Forum, World Bank, 2000).

- Corporate sustainability aligns an organization's products and services with stakeholder expectations, thereby adding economic, environmental and social value (PriceWaterhouseCoopers).

- Ethics: The science of morals in human conduct. (Oxford Dictionary).

- Ethical accounting is the process through which the company takes up a dialogue with major stakeholders to report on past activities with a view to shaping future ones. (John Rosthorn, "Business ethics auditing: More than a stakeholder's toy", in Journal of Business Ethics, 27(1-2), September 2000).

- Ethical auditing is regular, complete and documented measurements of compliance with the company's published policies and procedures (ibid.).

- Ethical bookkeeping is the systematic, reliable maintaining of accessible records for corporate activities which reflect on its conduct and behaviour (ibid.).

- Reputation Assurance: A number of common global principles for the business environment assembled to provide quantitative and trend information. (John Rosthorn, ibid.)

- Social Reporting: Non-financial data covering staff issues, community economic developments, stakeholder involvement and can include voluntarism and environmental performance. (Michael Hopkins)

- Sustainable Development: Environmental impact measurement, improvements, monitoring and reporting. (John Rosthorn, ibid.) 


\section{Annex II}

Table 1. CSR and profits, likely benefits and costs

\begin{tabular}{|c|c|c|}
\hline Stakeholder group & Benefits & Costs \\
\hline Directors & More independent non-executive directors & More meetings and briefings \\
\hline \multirow[t]{3}{*}{ Shareholders } & Increased investment from & CSR premium on all company activities \\
\hline & Ethically based pension funds & such as increased reporting costs, more \\
\hline & & openness, etc. \\
\hline \multirow[t]{4}{*}{ Managers } & Better HR policies lead to increased motivation & Increased training in ethics \\
\hline & More awareness of ethical issues from focus & Focus group sessions and reporting \\
\hline & group sessions lead to more confidence about & \\
\hline & employees. & \\
\hline \multirow[t]{8}{*}{ Employees } & Better HR policies lead to increased motivation & Inclusion of ethics training \\
\hline & Good ethical conduct by superiors lead to & More intra-company communications \\
\hline & improved productivity. & \\
\hline & Less labour relations disputes, less strikes & More effort on labour relations \\
\hline & Better working conditions & \\
\hline & Good company CSR leads to easier recruit- & \\
\hline & ment of high flyers and young people & $\begin{array}{l}\text { Will need to implement human rights } \\
\text { policies }\end{array}$ \\
\hline & Reduced costs of recruitment & \\
\hline \multirow[t]{6}{*}{ Customers } & Move to ethical consumption captured by & $\begin{array}{l}\text { Costs of goods may increase in the short } \\
\text { term }\end{array}$ \\
\hline & Company & \\
\hline & Less disputes & \\
\hline & Advertising can cite CSR & \\
\hline & Enhanced reputation & \\
\hline & Brand quality recognition & \\
\hline \multirow[t]{2}{*}{ Subcontractors /Suppliers } & Better quality inputs & Cost of inputs may increase in short-term \\
\hline & Less harmful effect on public image & \\
\hline \multirow[t]{2}{*}{ Community } & More willingess to accept new investments & $\begin{array}{l}\text { Requires continual interaction with } \\
\text { community }\end{array}$ \\
\hline & Improved public image & \\
\hline \multirow[t]{6}{*}{ Government } & More confidence in company. & Costs of adhering to new regulations will \\
\hline & Fewer legal battles, no new & increase. \\
\hline & Potentially harmful legislation. & \\
\hline & More favourable trading regime & \\
\hline & More willingness to accept & \\
\hline & Expansion or downsizing & \\
\hline \multirow[t]{2}{*}{ Environment } & Less legal battles & $\begin{array}{l}\text { Investment in environmental damage } \\
\text { control. }\end{array}$ \\
\hline & Improved public image & \\
\hline
\end{tabular}


Annex III

Table 2. Most well-known business principles

\begin{tabular}{|c|c|c|}
\hline $\begin{array}{l}\text { Government and intergovernmental } \\
\text { Initiatives }\end{array}$ & Date & Main issues \\
\hline ILO Tripartite Declaration on TNCs & Geneva,1977 revised March 2000 & Employment \\
\hline OECD Guidelines & Paris, 1976, revised June 2000 & $\begin{array}{l}\text { Multi-stakeholder including employment and triple } \\
\text { bottom line }\end{array}$ \\
\hline UN Global Compact & New York, July 2000 & Human rights, labour and environment \\
\hline UNEP Financial Statement & Paris, 1992, revised May 1997 & Environment \\
\hline EU Principles & Brussels, 2001 ; revised 2002 & Multi-stakeholder \\
\hline Voluntary Principles on & Wash. DC and London, Dec. 2000 & Security and human rights for \\
\hline Security and Human Rights, US \& UK Govt. & London, Dec. 2000 & Extractive and energy industries \\
\hline US Model Business Practices, & Wash. DC, 1996 & $\begin{array}{l}\text { Health and safety, labour, environment, corruption, } \\
\text { community, law }\end{array}$ \\
\hline Ethical Trading Initiative, UK Gov and NGO & London, Sept 1998 & Labour practices essentially on trade links \\
\hline Company-led initiatives & Date & Main issues \\
\hline Caux Principles & Minnesota, 1994 & Multi-stakeholder \\
\hline Fair Labor Association (FLA), US & California, Nov 1998 & Labour practices \\
\hline Global Sullivan Principles & USA, Nov. 1999 & Mainly external stakeholders \\
\hline ICC Business Charter for Sustainable Dev. & Brussels, 1991 & Environment, health and safety \\
\hline World Economic Forum & Davos/Geneva, 2002 & Corporate governance, [word missing] \\
\hline NGO-led initiatives & Date & Main issues \\
\hline AccountAbility 1000 & $\begin{array}{l}\text { London, } 1999 \\
\text { (revised 2002) }\end{array}$ & $\begin{array}{l}\text { Social and ethical 'assurance' not environment, } \\
\text { Stakeholder model (SK not defined) }\end{array}$ \\
\hline Amnesty International HR guidelines & London, Sept. 1998 & Human rights and security \\
\hline CERES Principles & USA, 1989 & Environmental ethical standards \\
\hline Global Reporting Initiative (GRI) & Boston, 1997 revised 2002 & Multi-stakeholder, triple bottom line indicators \\
\hline ICFTU Code of Labour Practice & Brussels/Geneva, 1997 & Labour and trade union issues \\
\hline SA8000 & London, 1998 (revised 2002) & Says CSR, but is mainly labour \\
\hline Interfaith Center Global Codes of Conduct & New York, 1995 & \\
\hline Social Venture Network & Brussels, 1999 & CSR multi-stakeholder, corporate \\
\hline Standards on CSR & & Governance mentioned, social audits \\
\hline Sigma Sustainability Principles & London, 1999 & $\begin{array}{l}\text { Multi-stakeholder bias toward Environment, no } \\
\text { management shareholders }\end{array}$ \\
\hline Q-Res Codes of Ethics & Italy, 1999 & Multi-stakeholder \\
\hline Governance initiatives & Date & Main issues \\
\hline General Motors Board Guidelines & Detroit & Management \\
\hline OECD Principles/ & Paris & Management \\
\hline \multicolumn{3}{|l|}{ Millstein Report International } \\
\hline Bosch Report, Australia & Australia & Management \\
\hline Merged Code Recommendations, Belgium & Brussels & Management \\
\hline Turnbull Report, UK & London & Management \\
\hline King Report, South Africa & Johannesburg, 2002 & Management and ethics \\
\hline King Report, Commonwealth & London, 2001 & Management and ethics \\
\hline World Bank Corporate & Wash., D.C., 2000 & Management and finance \\
\hline Governance Forum & & \\
\hline
\end{tabular}





\section{Policy Integration Department Working Papers prepared for the World Commission on the Social Dimension of Globalization}

No. 16 International finance: Meeting the needs of people in developing countries, José Guilherme Almeida dos Reis

No. 17 The gender dimensions of the globalization of production, Stephanie Barrientos, Naila Kabeer and Naomi Hossain

No. 18 Social exclusion in the context of globalization, Jan Breman

No. 19 Gender and globalization: A macroeconomic perspective, Çağatay Nilüfer and Ertük Korkurt

No. 20 Globalization, social exclusion, and work: with special reference to informal employment and gender, Marilyn Carr and Martha Chen

No. 21 Resources for social development, Anthony Clunies Ross

No. 22 Does the new international trade regime leave room for industrialization policies in the middle-income countries?, Alisa DiCaprio and Alice Amsden

No. 23 Social dimension of globalization in Latin America: Lessons from Bolivia and Chile, Alvaro García Hurtado

No. 24 Globalization: Social impact and policy actions: A partly annotated bibliography, Bernhard Gunter and Rolph van der Hoeven

No. 25 The social dimension of global production systems, Susan Hayter

No. 26 Reforming global economic and social governance: a critical review of recent programmatic thinking, Jeremy Heimans

No. 27 Corporate social responsibility: An issues paper, Michael Hopkins

No. 28 Upgrading in global value chains, John Humphrey

No. 29 Implications of globalization and economic restructuring for skills development in Sub-Sahara Africa, Richard K. Johanson

No. 30 The outcome and impact of the main international commissions on development issues, Frédéric Lapeyre

No. 31 Globalization and structural adjustment as a development tool, Frédéric Lapeyre

No. 32 Globalization and perceptions of social inequality, Malte Luebker

No. 33 The changing structure of trade linked to global production systems:

What are the policy implications?, William Milberg

No. 34 Corporate social responsibility: An overview of principles and practice, Jill Murray

No. 35 Inclusive development strategy in an era of globalization, Ignacy Sachs

No. 36 Social consequences of the globalization of the media and communications sector: Some strategic considerations, Seán Ó. Siochrú

No. 37 Globalization, history and international migration - A view from Latin America, Andrés Solimano

No. 38 Towards a different kind of globalization, or how the anti-globalizers view the world, Gijsbert van Liemt 